\title{
ANALISIS KRUPUK TEMPE ASLI SIDOARJO
}

\section{Nungky Andriana, Tri lindawati, Mei sinta susangko putri}

\author{
Universitas Nahdlatul Ulama Sidoarjo \\ Email: nungkyandriana12@gmail.com
}

Sidoarjo adalah nama dari salah satu kabupaten yang ada di Jawa Timur, yang mempunyai lambang udang dan bandeng. Sebagian wilayahnya adalah penghasil tempe. KBBI (2018) menunjukkan bahwa Sidoarjo merupakan sebuah kabupaten yang ada di Provinsi Jawa Timur Indonesia, Kabupaten Sidoarjo terletak diantara 11205' dan 11209' Bujur Timur dan antara 703' dan 703' 705' Lintang Selatan. Terdapat lambang ikan bandeng dan ikan udang membentuk huruf "S" melambangkan hasil tambak dalam daerah Kabupaten Sidoarjo. Bentuk huruf "S" ini melambangkan huruf pertama dari Sidoarjo.

\begin{tabular}{|l|l|}
\hline \multicolumn{2}{|c|}{ Perbatasan Kabupaten Sidoarjo } \\
\hline Utara & $\begin{array}{l}\text { Kota Surabaya dan Kabupaten } \\
\text { Sidoarjo }\end{array}$ \\
\hline Selatan & Kabupaten Pasuruan \\
\hline Barat & Kabupaten Mojokerto \\
\hline Timur & Selat Madura \\
\hline
\end{tabular}

Tabel1.1 Perbatasan Kabupaten Sidoarjo 
Karena salah satu nama kabupaten yang mempunyai moto Sidoarjo bersih hatinya. Bidang pemdes (2016) mengatakan bahwa Kabupaten Sidoarjo merupakan daerah pertanian yang subur sebagai lumbung pangan, mempertahanankan pertanian yang maju agar bisa swasembada pangan dengan cara intensifikasi pertanian dan menggunakan mekanisme teknologi tepat guna. Disamping itu, dukungan industri menjadi faktor penting sebagai perwujudan kesejahteraan, maka kedua hal itu harus berkembang secara serasi. Selain itu, masyarakat Kabupaten Sidoarjo berbudaya dalam lingkungan hidup yang bersih, rapi, serasi, hijau dan nyaman.

Setiap hari bisa memproduksi krupuk tempe. KBBI (2018) mengatakan bahwa tempe merupakan makanan yang terbuat dari fermentasi dari biji kedelai mempunyai aroma yang khas, tempe dari biji kedelai berwarna putih. Tempe berasal dari bahasa Jawa kuno. Komposisi kandungan gizi yang terdapat dalam tempe adanya protein, lemak, dan karbohidrat tidak banyak berubah dibandingkan dengan biji kedelai.

PT. Krupuk Sidoarjo. Lestari, dkk (2013) mengatakan bahwa panganan dari olahan kedelai ini banyak sekali peminatnya, tempe merupakan panganan yang sehat dan memenuhi nutrisi dengan harga yang terjangkau. Nainggolan (2016) Berikut adalah grafik produksi dan konsumsi kedelai dari tahun 2009-2014. 


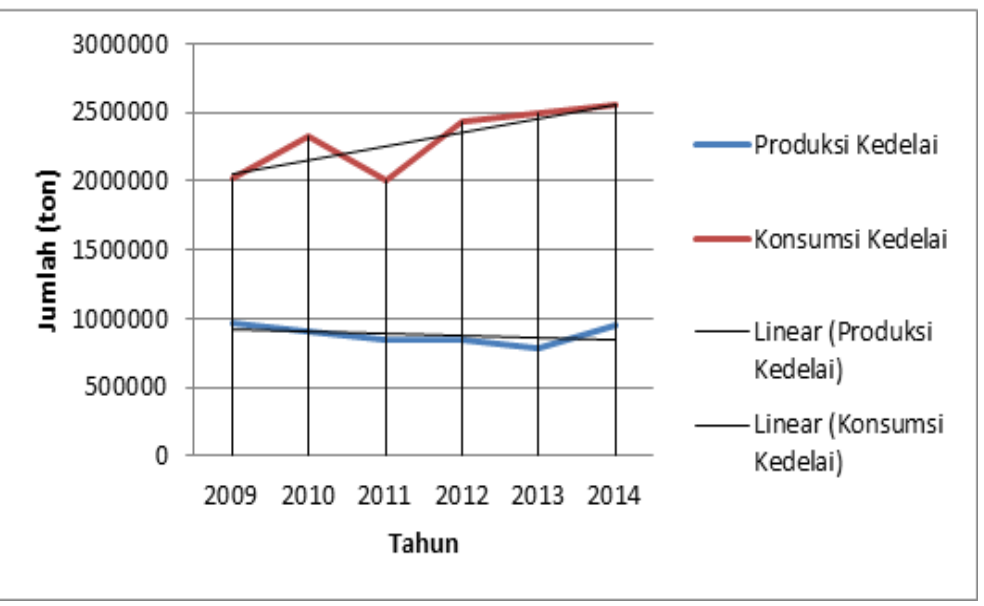

Tabel 1.2 grafik produksi dan konsumsi kedelai

MSDM (Manajemen Sumber Daya Manusia) digunakan sebagai penunjang untuk perekonomian di Sidoarjo. Dengan adanya MSDM yang bagus, maka akan dapat meningkatkan perekonomian pula. Kegiatan tersebut digunakan dalam kehidupan sehari-hari, karena dengan kemajuan jaman, tentunya standart yang diperlukan atau diberikan juga berkembang. Pemerintah sendiri juga sudah banyak melakukan pelatihan, seminar, dan penyuluhan yang dimaksudkan untuk para pengusaha-pengusaha yang ada di wilayah Sidoarjo sehingga mereka dapat memperbaiki kwalitas SDM yang mereka miliki (Asitah et al., 2018). Sidoarjo akan lebih meningkatkan kualitas produk krupuk tempe. Kualitas tempe di Sidoarjo akan lebih ditingkatkan tidak hanya memproduksi tempe biasa tetapi juga meningkatkan dengan 
memproduksi krupuk tempe dengan kemasan yang menarik. Dengan menambahkan berbagai macam varian rasa ke dalam krupuk tempe agar mempunyai berbagai macam rasa seperti rasa balado, rasa manis, rasa keju dan rasa pedas.

Lestari, dkk (2013) mengatakan bahwa panganan dari olahan kedelai ini banyak sekali peminatnya, tempe merupakan panganan yang sehat dan memenuhi nutrisi dengan harga yang terjangkau.

Krupuk tempe di Sidoarjo biasanya sering mengikuti bazar atau pameran agar lebih dikenal oleh masyarakat, bisa juga dititipkan di tokoh-tokoh. Kopitangsel (2017) mengatakan bahwa pameran bisnis di pusat keramaian menjadi ajang promosi yang efektif. Pasalnya, event pameran bisnis acap kali ramai dipadati pengunjung, baik yang sekadar melihat-lihat atau memang ingin mencari suatu produk. Apalagi di akhir pekan seperti hari sabtu dan minggu, biasanya pengunjung tambah ramai berjejalan.

Dijual di seluruh wilayah sidoarjo seharga 5 ribu rupiah perbungkus. Kusdianto (2018) mengatakan bahwa strategi penetapan harga jual produk memiliki peran penting yang sangat besar dalam mempengaruhi proses penjualan. Harga menjadi salah satu pertimbangan penting dalam keputusan pembelian konsumen

Berkaitan dengan apa yang sudah diterangkan dan diungkapkan pada uraian diatas 
diperoleh permasalahan yang bisa untuk dikaji seperti berikut ini:

1. Apa yang menjadi kekuatan dan kelemahan untuk Krupuk Tempe Asli Sidoarjo?

2. Apa yang dapat menjadi peluang dan ancaman untuk Krupuk Tempe AsliSidoarjo?

3. Apa strategi untuk Krupuk Tempe Asli Sidoarjo?

\section{METODE}

KBBI (2018) Penelitian kualitatif adalah penelitian tentang riset yang bersifat deskriptif dan cenderung menggunakan analisis. Proses dan makna (perspektif subjek) lebih ditonjolkan dalam penelitian kualitatif. Landasan teori dimanfaatkan sebagai pemandu agar fokus penelitian sesuai dengan fakta di lapangan. Selain itu landasan teori juga bermanfaat untuk memberikan gambaran umum tentang latar penelitian dan sebagai bahan pembahasan hasil penelitian. Terdapat perbedaan mendasar antara peran landasan teori dalam penelitian kuantitatif dengan penelitian kualitatif. Dalam penelitian kuantitatif, penelitian berangkat dari teori menuju data, dan berakhir pada penerimaan atau penolakan terhadap teori yang digunakan; sedangkan dalam penelitian kualitatif peneliti bertolak dari data, memanfaatkan teori yang ada sebagai bahan penjelas, dan berakhir dengan suatu "teori". 
Kriyantono, Rachmat (2006) menyatakan bahwa "riset kualitatif bertujuan untuk menjelaskan fenomena dengan sedalam-dalamnya melalui pengumpulan data sedalam-dalamnya.". Penelitian kualitatif menekankan pada kedalaman data yang didapatkan oleh peneliti. Semakin dalam dan detail data yang didapatkan, maka semakin baik kualitas dari penelitian kualitatif ini. Berbeda dengan kuatnitatif, objek dalam penelitian kualitatif umumnya berjumlah terbatas Penelitian kualitatif jauh lebih subjektif daripada penelitian atau survei kuantitatif dan menggunakan metode sangat berbeda dari mengumpulkan informasi, terutama individu, dalam menggunakan wawancara secara mendalam dan grup fokus. Sifat dari jenis penelitian ini adalah penelitian dan penjelajahan terbuka berakhir dilakukan dalam jumlah relatif kelompok kecil yang diwawancarai secara mendalam.

Singarimbun (1995) mengatakan bahwa, penelitian ini merupakan penelitian survei, dengan mengandalkan kuesioner sebagai instrumen pengumpulan data. Metode (Confirmatory research) penelitian ini dimaksudkan sebagai rancangan untuk menguji atau membuktikan sesuatu melalui pengujian hipotesis.

(Malhotra, 2006) Data di analisis dengan analisis dekriptif dan tabulasi silang. Penelitian ini menggunakan metode analisis cluster yang bertujuan untuk mengelompokkan obyek 
berdasarkan kesamaan karakteristik diantara obyek-obyek tersebut.

\section{Lumpur Sidoarjo}

Lumpur Sidoarjo adalah suatu peristiwa bocornya pengeboran gas bumi yang terjadi di Kabupaten Sidoarjo salah satu Kabupaten di Jawa Timur. Kebocoran pengeboran gas bumi tersebut dilakukan atas kelalaian PT. Lapindo Brantas (Nahdiyah, et al., 2018).

\section{ANALISIS SWOT}

Kekuatan (Strength) krupuk Tempe

1. Dapat menguasai pasar lokal di wilayah perusahaan berproduksi.

2. Memahami selera konsumen dan kebutuhan akan panganan berkualitas dengan harga terjangkau.

3. Produk dapat bertahan 1-15 hari dalam kemasan

4. Harga merakyat

5. Bebas dari bahan pengawet kimia yang berbahaya

6. Berusaha menggunakan Brand sebagai proses pemasaran agar lebih di kenal

Kelemahan (Weakness) krupuk Tempe

1. Memiliki banyak pesaing 
2. Memerlukan biaya tambahan untuk membuat Brand lebih dikenal

3. Melihat kondisi cuaca panas atau tidak

Opportunity (Kesempatan) krupuk Tempe

1. Mengemas krupuk tempe semenarik mungkin untuk menarik para konsumen

2. Belum banyak produk tempe yang bermerek, berlogo, dan mencantumkan ferivikasi BPOM serta logo halal

Ancaman (Threats) krupuk Tempe

1. Harga bahan utama yakni kedelai yang tak menentu, terlebih lagi jika sedang melonjak naik

2. Pesaing lain yang bergelut di bidang yang sama

\begin{tabular}{|l|l|}
\hline \multicolumn{2}{|c|}{ MENETAPKAN TARGET KONSUMEN } \\
\hline Jenis Kelamin & laki-laki / wanita \\
\hline Rentang Usia & $8-50$ tahun \\
\hline Tipe pekerjaan & $\begin{array}{l}\text { pelajar, mahasiswa, pegawai } \\
\text { swasta/negri }\end{array}$ \\
\hline
\end{tabular}


Karakteristik penting lainnya

menyukai makanan renyah, ngemil

\section{HASIL DAN PEMBAHASAN}

Warga sidoarjo gemar dengan budaya seperti batik (Yuniarti et al., 2018). Target dalam pemasaran produk krupuk tempe asli Sidoarjo, target yang harus dipenuhi bukan hanya kemasannya yang harus diperbarui melainkan wilayah penjualan harus lebih marambat luas lagi. Menetapkan target konsumen juga sangat penting dan sangat berpengaruh.

Tabel 1.3 Menetapkan Target Konsumen (Yacob Aditama)

\section{HASIL ANALISIS}

Menurut Doman (2002), analisis jawaban responden dalam kuesioner dapat dilakukan melalui analisis tren, analisis similaritas, analisis kontradiksi, serta analisis odd grouping. hasil analisis yang lebih sering membeli atau mengonsumsi Krupuk Tempe Asli Sidoarjo mayoritasnya adalah kaum wanita atau ibu-ibu rumah tangga yang lebih sering mengonsumsi.

\section{KESIMPULAN}

Dalam memproduksi harus lebih cermat dalam memilih dan menjaga kwalitas bahan-bahan yang dibutuhkan agar hasilnya maksimal dan tidak mengurangi rasa, supaya pelanggan tidak pindah 
ke produk yang lain agar pelanggan puas dengan Krupuk Tempe Asli Sidoarjo.

\section{REFERENCES}

KBBI (2018)

http://ejournal.uajy.ac.id/6331/1/JURNAL\%20RISE T\%20PASAR\%20KERIPIK\%20TEMPE\%20SA GU.pdf

http://sid.sidoarjokab.go.id/index.php/first/artikel/11 $\underline{9}$

https://lukasbn.wordpress.com/2016/03/03/swasem bada-kedelai-yakin/

https://www.kopitangsel.com/artikel/

http://www.pojokbisnis.com/pemasaran/strategipenetapan-harga-faktor-yang-menentukanharga-jual-produk

Asitah, N., Maula, I., Munjidah, A., Nahdiyah, K., Yuniarti, D., Sholichah, S. A., Purnomo, A., Rosyidah, E., Anam, Fatkul., Achmadi, A.A., Fahmi, M. (2018, May 25). Urgensi Aktualisasi Manajemen Sumber Daya Manusia untuk Resurgensi Perekonomian di Sidoarjo. http://doi.org/10.17605/OSF.IO/TG79P

Nahdiyah, K., Asitah, N., Maula, I., Munjidah, A., Yuniarti, D., Sholichah, S. A., Purnomo, A., 
Rosyidah, E., Achmadi, A.K., Anshori, A., Anam, F. (2018, May 27). Konsekuensi

Lumpur Sidoarjo terhadap Sidoarjo dengan Perspektif Multidimensi.

http://doi.org/10.17605/OSF.IO/N32BE

Yuniarti, D., Asitah, N., Nahdiyah, K., Maula, I., Munjidah, A., Sholichah, S. A., Purnomo, A., Rosyidah, E., Istiqomah, N., Anam, F., \& Achmadi, A. K. (2018, May 25). Batik Jetis Sidoarjo Sebagai Destinasi Ekskursi Impresif. http://doi.org/10.17605/OSF.IO/XRY58 